Penultimate version. Final version is forthcoming in Philosophy Compass

(http://onlinelibrary.wiley.com/journal/10.1111/(ISSN)1747-9991)

\title{
Affectivity in Heidegger II: Temporality, Boredom, and Beyond
}

\author{
Lauren Freeman \& Andreas Elpidorou \\ University of Louisville
}

In "Affectivity in Heidegger I: Moods and Emotions in Being and Time", we explicated the crucial role that Martin Heidegger assigns to our capacity to affectively find ourselves in the world. There, our discussion was restricted to Division I of Being and Time (BT). Specifically, we discussed how Befindlichkeit as a basic existential (i.e., a structure of Dasein's being that constitutes both the manner in which Dasein exists and discloses itself), and moods as the ontic counterparts of Befindlichkeit (i.e., the pre-reflective ways in which Dasein relates to and discloses the world) make circumspective engagement with the world possible. Indeed, according to Heidegger, it is primarily through moods that the world is 'opened up' and revealed to us as a world that is suffused with values and entities that already matter to us. In this companion essay, our aim is to expand our analysis of affectivity in the following ways: first, we revisit our discussion of Befindlichkeit in light of Heidegger's discussion of temporality in Division II of BT; second, we discuss the basic or fundamental mood (Grundstimmung) of boredom (Langeweile) and its ontological significance; we conclude by providing a brief characterization of how Heidegger's notion of mood changes in his later thinking.

\section{Befindlichkeit and Temporality}

The sense ( $\operatorname{Sinn}$ ) of the being of Dasein, Heidegger announces very early on in Division I of BT, is temporality (BT 38/17). ${ }^{1}$ An elaboration of this claim, however, does not come until

\footnotetext{
$1 \quad$ All references to Being and Time will be indicated by 'BT' followed by the English and German pagination. The German pagination corresponds to the seventh and later editions of the text. Unless otherwise stated, we will be using Macquarrie and Robinson's translation of the text. References to The Fundamental Concepts of Metaphysics (Die Grundbegriffe der Metaphysike) will be indicated by 'FCM' followed by the pagination of McNeil and Walker's (1995) English translation and by the pagination corresponding to the German text
} 
Division II, where he sets out to re-describe the hitherto provided account of Dasein's fundamental ontological structures in terms of temporality. The existential analytic of Dasein was always designated as "preparatory" and so a return to it is not conceived by Heidegger to be unnecessary, redundant, or in any way gratuitous. Rather, for Heidegger, a thorough and proper understanding of temporality is needed in order to explicate both what constitutes and enables human existence, as well as the character of the many distinct and concrete manifestations of such an existence. ${ }^{2}$ In describing and explaining Heidegger's view of affectivity in BT, we follow Heidegger's hermeneutical lead.

After having already provided an account of affectivity that was based primarily on Division I, we now turn to a re-description of this account in terms of temporality. All too often, expository accounts of Heidegger and affectivity stop short of bringing forth the temporal character of Befindlichkeit and mood. ${ }^{3}$ However, if Heidegger is right to insist that temporality bears an intimate relation to Dasein - temporality is indeed the transcendental condition for the possibility of Dasein's distinctive way of being (BT 371/324) - then any explication of Heidegger's views on affectivity that leaves the relationship between temporality and Befindlichkeit unspecified will be importantly incomplete.

\subsection{Dasein's Temporality}

Dasein is an entity whose very being is an issue for it: in existing, Dasein inevitably chooses how to exist. Unlike other entities that merely subsist, Dasein exists (BT 32/12) insofar as Dasein is what it understands ${ }^{4}$ itself to be and it understands itself by projecting itself into

(second edition, 1992). All other references to Heidegger's works will be indicated by the volume and page number of his Gesamtausgabe (GA). Since most English translations of the Gesamtausgabe include the respective page numbers of the original German edition, we do not list the pagination of the translation. The only exception is Wegmarken (GA 9). References to Wegmarken will include the relevant page number in GA 9 (1976 edition) followed by the page number in Pathmarks. Complete bibliographical information for the Englishlanguage translations of all the volumes of the Gesamtausgabe cited in this essay is given in the references.

2 Heidegger assigns to temporality an even more important role: at least provisionally, time needs to be interpreted "as the possible horizon for any understanding of Being whatsoever" (BT 1/1). In other words, a proper understanding of the character of time is that which allows us to develop concretely the question of the meaning of Being. The project of showing precisely how the understanding of Being as such is grounded in temporality is not developed in BT, though hints are given in $\$ 69$. A more developed account can be found in his 1927 summer semester lecture, The Basic Problems of Phenomenology (GA 24).

3 Slaby's remarkably clear essay on affectivity is a notable exception. See Slaby (2015).

$4 \quad$ "Understanding" (Verstehen) does not refer to a rational or cognitive capacity; rather, it designates one of Dasein's existential structures and also one of the constituents of its disclosedness (BT 182f./143f., 
some possibility of being. Dasein, as an entity that constitutes itself by defining and determining its own possibilities (possibilities that it both inherits and projects for itself), is always ahead of itself (BT 236/192). However, Dasein is not just ahead of itself; it is not mere potentiality. Rather, Dasein is ahead of itself as always already being-in-the-world. That is, who and what Dasein has been - the context in which Dasein exists and has existed - is intertwined with who Dasein can become, namely, with the possibilities that Dasein can project (BT 236/192, 416/364, 458/406). Finally, as Dasein, we project certain already delineated possibilities because they matter to us and we do so while always already being absorbed in the holistically meaningful world of our concern alongside those entities with which we interact.

These three fundamental aspects of Dasein's being - being abead of itself, being already in a world, and being alongside entities of its concern - correspond respectively to Dasein's existence, facticity, and falling. Taken together, they constitute Dasein's ontological structural whole, or what Heidegger calls "care" (Sorge) (BT 237/192). Each of the three elements of Dasein's ontological structural whole is grounded in originary temporality (BT 375/327). "Temporality," Heidegger writes, "makes possible the unity of existence, facticity, and falling, and in this way constitutes primordially the totality of the structure of care" (BT 376/328). ${ }^{5}$ The sense of Dasein's being - that which makes Dasein's being possible - is originary temporality (BT 374/326, 401-402/350-1, 416/365). ${ }^{6}$

But what is originary temporality?

The character of originary temporality is revealed in anticipatory resoluteness (vorlaufende Entschlossenbeit). This is because in anticipatory resoluteness, the three elements of Dasein's care structure are disclosed in a way that makes transparent what they presuppose, namely, originary temporality (BT 351/304). Resoluteness is a distinctive type of disclosedness through which Dasein becomes authentically transparent to itself (BT 345346/299). In everydayness, Dasein is lost to itself in the 'they' (das Man), but in resoluteness, Dasein lets itself "be summoned out of [its] lostness in the 'they" (BT 345/299). Resoluteness, as a mode of being-in-the-world, does not detach Dasein from the world.

188/148). Understanding means "to be projecting towards a potentiality-for-Being for the sake of which any Dasein exists" (BT 385/336).

$5 \quad$ In-depth and detailed discussions of Heidegger's account of originary temporality can be found in Blattner 2005, Dahlstrom 2001, Mulhall 1995, and Käufer 2013. Helpful overviews of BT and Division II can be found in Mulhall 1995, Polt 1999, and Vallega-Neu 2003.

$6 \quad$ For Heidegger's discussion of meaning see BT $\$ 32,370-1 / 324$. 
Quite the contrary: resoluteness "brings" Dasein back into its concernful relationships with entities and solicitous affairs with others (BT 344/298). Moreover and importantly, it does so in a manner that both discloses to Dasein "what is factically possible at that time" and it permits Dasein to take over such grounded possibilities in a way that is most genuinely its own (BT 345/298, 346/299). To be resolute, in other words, is to exist authentically by choosing to be oneself. ${ }^{7}$

But in order to be, or better, to become oneself, Dasein must exist in a way that holds in clear view what it really is: namely, a fundamentally thrown, conditioned, finite being. Dasein can become authentic (eigentlich), therefore, if its choices are revealed to itself as stemming from its thrown existence - one that is inevitable, beyond its total control, and indeed one for which Dasein itself can find no reason or ground. In addition, Dasein can become authentic only if through its choices, it also assumes responsibility for what and who it has been, is, and is becoming. At the same time, resoluteness requires not only that Dasein take over its thrownness, but also that Dasein exist with a certain comportment towards its own death. Heidegger calls this comportment "anticipation" (Vorlaufen). For Heidegger, death is the defining (im)possibility of Dasein's existence: it is most intimately its own and that which is capable of individualizing Dasein and allowing it to become its own authentic self. Dasein can authentically become itself only if it anticipates its own death: that is, by appreciating its finitude and projecting this possibility for itself (BT 302ff/262ff). For Dasein to exist authentically, it must acknowledge that at any moment, death is always a possibility and that its whole existence (and not just this or that relation) is at stake. In anticipating death, Dasein thus comes to see, understand, and even to embody the very contingency of its existence. Only by grasping its own existence in this manner can Dasein truly assume responsibility for living a life that is truly its own.

The upshot of the foregoing considerations is that resoluteness, as Dasein's authentic existence, necessarily involves the anticipation of its own death. "Resoluteness is authentically and wholly what it can be, only as anticipatory resoluteness" (BT 356/309; cf. 353/305). In anticipatory resoluteness, it becomes evident that Dasein as a being-possible viz., as an entity that constitutes itself through the possibilities it projects - is its own death. (Dasein, after all, “is its possibilities as possibilities” [BT 185/145]). Death, as that possibility

\footnotetext{
$7 \quad$ For more on Heidegger's technical and idiosyncratic account of authenticity, see Guignon 2000 and 2004, Carman 2005, Blattner 2013, and Dahlstrom 2014.
} 
that can never be actualized, as the possibility that is always to come, and as the possibility to come that is always and only mine, demonstrates that Dasein is fundamentally futurally oriented. This is because in anticipating its own death, Dasein is always coming towards itself. Heidegger calls Dasein's defining coming-towards (zukommt) itself the "primordial phenomenon of future" (BT 372/325). But Dasein can come towards itself only if it already is and already has been. Dasein can only become what it already is; in other words, its possibilities are grounded in and restricted by its thrownness. As such, Dasein can come towards itself only if it comes back to who it has already been (BT 373/326). This phenomenon of having been (Gewesenheit) corresponds to Dasein's originary past. Finally, anticipatory resoluteness is a mode of disclosure (BT 343/297). The manner in which anticipatory resoluteness discloses the 'there' and lets the entities of our circumspective concern present themselves to us is possible only in the present (Gegenwart) as "making present" or "enpresenting" (Gegenwärtigen) (ibid.). This making present corresponds to the originary present. Originary future and originary past presuppose each other and both release the originary present (ibid.).

Temporality, as the ontological structure that underpins and realizes the being of Dasein - what Heidegger calls both "originary time” (ursprüngliche Zeit) (BT 377/329) and "originary temporality" (ursprüngliche Zeitlichkeit) (BT 377/329, 379/331) - must be clearly distinguished from our ordinary conception of time, namely, a continuous and irreversible sequence of 'nows' (BT 464/422). It must also be distinguished from "world-time": our pretheoretical experience of time as a sequence of meaningful events. Originary time is drastically different from and also grounds these two conceptions of time (BT 378/329, 457/405, §81; Blattner 2005; Hoffmann 2005).

Originary temporality is not something that is. It is not an entity (BT 377/328; GA 21: 410; GA 20: 441-2). Moreover, the claim that 'care has temporality' cannot be taken to mean that the care-structure of Dasein occurs in time. On either understanding of originary temporality, Dasein's distinctive existence would cease to be insofar as it would be rendered a present-at-hand entity (BT 375/327). Originary temporality is only insofar as it temporalizes: "Temporality temporalizes, and indeed it temporalizes possible ways of itself" (BT 377/328). As Stephen Mulhall aptly and helpfully notes, originary temporality should be

\footnotetext{
8 Macquarrie and Robinson translate "ursprüngliche Zeit" as "primordial time" and "ursprüngliche Zeitlichkeit" as "primordial temporality."
} 
thought of as "akin to a self-generating and self-transcending process" (2005, 161; cf. Slaby 2015).

What is "essential" to originary temporality as temporalizing is its ecstatic nature (BT 377/329; GA 26: 254, 265-6). Each mode of temporality's self-constitution stands outside of itself, so to speak, and is always interrelated with the other two modes. In their ecstatic and horizonal ${ }^{9}$ unity, they make possible the different ways in which Dasein can relate to beings and to possibilities, including, most importantly, to Dasein's possibility of its impossibility (i.e., its existential death). Indeed, the ecstatic-horizonal unity of originary temporality makes transcendence possible (BT 401-2/350-1), constitutes the disclosedness of the 'there' (BT 416/365, 460/408, 463/410), and grounds both authentic and inauthentic ways of being (BT 377/328, 401/350). Thus, originary temporality, as "essentially a self-opening and expanding into a world" (GA 26: 271), is not only fundamentally unified, it is dynamically so. In its ecstatic-horizonal unity, the different ecstases are 'live' and can bring about different modes of temporalization, i.e., different ways of being (BT 378/329).

It is precisely this dynamic and fundamentally unified nature of temporality that allows us to understand both Heidegger's insistence that " $[\mathrm{t}]$ emporalizing does not mean a 'succession' of the ecstases" and his contention that "[t]he future is not later than having been, and this is not earlier than the present" (BT 401/350). The future is not later because the originary future is not "a 'now' which has not yet become 'actual”" (BT 373/325). Instead, the future is "the coming in which Dasein, in its ownmost potentiality-for-Being, comes towards itself" (BT 374/325). Originary future is the "primary meaning of existentiality" (BT 374/327): it is the way in which in every moment we are already ahead of ourselves and we determine who we are by having to choose who we will become from a set of unrealized possibilities. Future, in this ontological sense, thus takes primacy over the other modes of temporality (BT 378/329). It determines both how we recover our thrownness (our having been) and how we encounter our present situation. And yet, as noted above in our discussion of anticipatory resoluteness, the possibility of letting oneself come towards oneself also requires the originary past (having been): “Only in so far as Dasein is as 'I-am-as-having-been', can Dasein come towards itself futurally in such a way that it comes back" (BT 373/326). One can futurally come to oneself only if one exists as already having been. Stated otherwise:

$9 \quad$ "Ecstases are not simply raptures in which one gets carried away. Rather, there belongs to each ecstasis a 'whither' to which one is carried away. This 'whither' of the ecstasis we call the 'horizonal schema.' In each of the three ecstases the ecstatical horizon is different" (BT 416/365). See also GA 26: 269ff. 
what you are as Dasein is primarily an ability-to-be, but as an-ability-to-be, you are already thrown.

\subsection{The Temporality of Befindlichkeit: Having Been}

The temporal interpretation of the existential analysis of Dasein concludes neither with the demonstration that the condition for the possibility of Dasein's distinctive manner of being (i.e., care) is temporality, nor with an explication of the character of originary temporality. Rather, as Heidegger insists, “[t]o exhibit [care's] concrete temporal Constitution, means to give a temporal Interpretation of the items of its structure, taking them each singly: understanding, Befindlichkeit, falling, and discourse" (BT 384-5/335). It is only on the basis of such a temporal interpretation of each moment of the structure of care that Heidegger can bring to the fore the intrinsically temporal nature of Dasein's disclosedness ( $(56)$, its transcendence $(\$ 69)$, and its everydayness (\$71). For our purposes, it is to Heidegger's discussion of the temporality of Dasein's disclosedness that we must turn in order to come, finally, to his account of the temporality of affectivity.

For Heidegger, moods (Stimmungen) are the ontic manifestations of Befindlichkeit and the pre-reflective ways in which Dasein relates to and discloses the world. They shape the manner in which the world appears to Dasein and they 'open up' the world for Dasein insofar as they are constitutive of Dasein's capacity to be affected. Dasein always finds itself in the world in some mood or other and it discloses itself and the world moodwise. For the most part, we neither cause nor choose our moods; rather they "assail us." (BT 176/136) They come neither from 'outside' (as if Dasein were a subject) nor from 'inside' (as if they were narrowly individuated mental states), but rather arise out of our being-in-the-world. They are "based upon" our thrownness in the world (BT 390/339), revealing in each case how we find ourselves (sich befinden). Moods disclose to Dasein the "that-it-is of its own thrownness" (BT 390/340). They expose Dasein's inherited burden of its existence (ibid.): that Dasein is here in this particular situation; a situation that it did not choose and that it cannot fully control; and yet a situation that Dasein must, in existing, take over and make its 
own (BT 173-175/135f, 223-224/179, 264/221, 321/276, 329-330/284, 388-389/339f). ${ }^{10}$

For the most part, the manner in which moods disclose the burden of our existence is by turning us away from it: we do not confront our thrownness explicitly, yet it is always there, conditioning our existence.

The revelatory function inherent in and fundamental to moods is possible, existentially, only if the meaning of Dasein's being “is as having been” (BT 340/390). That is, moods can disclose the inherited burdensome character of Dasein's existence only if Dasein's ontological structure is enabled by the originary past. Originary past is not a thing of the past - in fact, it is neither a thing nor past (in our ordinary temporal understanding of the term). Rather, originary past is a dimension of the ontological structure of Dasein's being thus, "“as long as' Dasein factically exits, it is never past [vergangen], but it always is indeed as already having been, in the sense of the "I-am-as-having-been" (ibid.; cf. BT 373/326). It is on account of this feature of Dasein's being that it affectively finds itself through moods (BT $390 / 340)$.

The fact that Befindlichkeit is grounded primarily in the originary past (having been) has important ramifications for the nature of affectivity. First, it illustrates that the basic character of mood lies in bringing Dasein back to something. Mood affectively discloses to Dasein that and how it has already been and in so doing, it determines for Dasein, at least in part, what and who it can become. Second, and relatedly, the manner in which we affectively find ourselves is grounded primarily, but not exclusively, in the originary past. Befindlichkeit is grounded in the originary past insofar as it is the past that "modifies" (viz., temporalizes) the originary future (coming towards) and the present (BT 390/340). As one of the ecstases of originary temporality, the originary past is always dynamically intertwined with the originary future and the originary present. Thus, moods bring Dasein back to itself, but they do so always by "letting-something-come-towards-itself" and by making entities present (BT 391/341). Such an interconnection between the ecstases of temporality underscores the unity of the structures that constitute Dasein's disclosedness (BT 385/335, 401/350). Most importantly, at least for present purposes, the dynamic interconnection between the ecstases of originary temporality is key for understanding the differences between the various ways of affectively finding oneself in the world.

10 For a more extensive and complete discussion of moods, their revelatory function, and their relationship to emotions and to Befindlichkeit, see the companion piece to this essay (Elpidorou and Freeman 2015). 


\subsubsection{Fear, Anxiety, and a bit of Hope}

Heidegger makes this last point explicitly in his discussion of the distinction between fear and anxiety in Division II of BT. His aim in these dense paragraphs of $\$ 68$ is to demonstrate both how fear (Furcht) and anxiety (Angst) are grounded in the having been and how the dynamic interconnection between the ecstases of originary temporality is capable of individuating the two. "Fear," Heidegger states, "is a fearing in the face of something threatening - of something which is detrimental to Dasein's factical potentiality-for-Being" (BT 391/341). Fear is disclosive both of the world (in that it 'opens up' a world of harms and threats) and of our selves. Indeed, as Heidegger emphasizes, "[f]ear always reveals Dasein in the Being of its 'there', even if it does so in varying degrees of explicitness" (ibid.). It is this last aspect of fear that makes transparent the existential meaning of fear, for it shows how fear is grounded in the originary past (having been). Although there is a sense in which fear is futural - after all, we are afraid of things to come and specifically, of what will become of us - this aspect of fear is only possible insofar as "in fear the awaiting lets what is threatening come back to one's factically concernful potentiality-for-Being" (BT 391/341). In other words, fear is not simply the expectation of something threatening that is forthcoming; rather, it is the expectation that what is forthcoming can come back to us and affect us. The point is that we can be affected only if we are already "ecstatically open" (ibid.), or equivalently, if we are temporal in the sense that we have been and are always coming towards ourselves by projecting possibilities for ourselves.

But how exactly is the distinctive affective nature of fear to be explained in terms of its temporal character?

The answer to this question lies in the specific mode of having been that characterizes fear. Fear, according to Heidegger, brings Dasein back to itself but in a particular manner that involves a forgetting, which is "an inauthentic way of having been" (BT 389/339). Fear involves forgetting but not insofar as Dasein suffers some kind of amnesia. "Forgetting is not nothing... it is rather a 'positive' ecstatical mode of one's having been" (ibid.). It is a specific way of relating to and finding (or in this case, losing) oneself. In fear, what Dasein forgets is its own thrownness and it does so because fear closes it off. 
When afraid, we no longer 'see' who we are as having been (BT 388-9/339). As such, the burdensome character of existence does not vanish, yet we are turned away from it.

Forgetting, as an inauthentic mode of having been, modifies Dasein's being. As such, in fear, Dasein exists inauthentically. This is because if one fails to notice one's thrownness then one cannot take it over. If this is the case, then one cannot take responsibility for one's choices; and as a result, one fails to become oneself (BT 373/326). Forgetting thus renders Dasein's comportment to its future inauthentic. In fear, Dasein does not project for itself its most intimate and defining possibility (namely, its ownmost potentiality-of-being: its own death). Instead, it projects for itself that with which it concerns itself most immediately (BT 386/337). In fear, Dasein does not anticipate its ownmost possibility; rather it merely “awaits" (erwarten) it (ibid.).

Heidegger's point cannot be that in fear one never projects one's own death. Rather, his point is that although in fear one comports oneself towards the possibility of one's death, one fails to assume - perhaps due to the urgency of the situation - an authentic comportment. But here one must press further: why doesn't fear involve an authentic comportment towards death? A hint is found in Heidegger's claim that the possibilities that one projects for oneself in fear have already been discovered circumspectively (BT 392/342). That is, if one projects for oneself such possibilities, then one defines oneself in terms of one's concerns. One does not first decide who one really is and then choose what to do. An authentic comportment towards one's death is one that individualizes Dasein. But fear, which involves waiting and as such, immersion in the world of concern, fails to do that. In running from a predator, for instance, I project for myself the possibility of my own death. Yet, I do so in such a way that I fail to give my life meaning: I understand myself as the entity that needs to escape, as an entity that runs quickly, or as an entity that can hide itself. Because in such a context I fail to see my mortality as a source of meaning, as a call to take action and responsibility for my life, and as a way of grasping and living in the contingency of life, I am not existing authentically. Thus, even if in fear one projects for oneself the possibility of death, that possibility does not come back to oneself authentically: it does not enhance one's existence in any way.

Lastly, the inauthentic past (forgetting) and inauthentic future (awaiting) of fear also release an inauthentic present. What is made present in fear is "a jumble of hovering possibilities" (BT 392/342): Dasein can save itself by doing this or that. Such an array of 
possibilities "bewilders" Dasein for it "lets [Dasein] drift back and forth between 'worldly" possibilities which it has not seized upon" (BT 394/344). The temporal structure of fear not only affords fear its existential meaning (i.e., it makes fear possible), it also accounts for its phenomenological character. In fear one "backs away in bewilderment;" one finds oneself in an evasive state of indecisiveness and one forgets, loses, and fails to properly understand oneself (BT 392/341). Fear, Heidegger concludes, is primarily grounded in a forgetting that modifies the future into an inauthentic awaiting and the present into an inauthentic making present of a set of contingent and instrumental possibilities (BT 393/342).

Although fear and anxiety bear certain formal similarities, they correspond to two importantly different ways of affectively finding oneself. We fear something that is threatening, dangerous, or detrimental to us. Fear arises out of, and indeed on account of, our concernful engagement with the world (BT 180/141, 399/344). On the contrary, no innerwordly entity can be the occasion for or cause of anxiety. Instead, "[a]nxiety springs from Dasein itself... [it] arises out of Being-in-the-world as thrown" (BT 393/344). Dasein is anxious for itself, for its individual being-in-the-world; and at the same time, Dasein is anxious about itself (BT 393/343). In anxiety, all environmental handy entities are disclosed as empty of relevance and significance. The present-at-hand, however, is not absent, nor is it rendered invisible to us. Instead, it is encountered in an unfamiliar and rather disconcerting light, namely, as bereft of any involvement whatsoever (BT 393/343). Anxiety does not blind Dasein; rather, it allows it to 'see' and to understand its predicament differently. When in the grip of anxiety, the world "has sunk into insignificance" (ibid.). As a consequence, our life as hitherto defined and understood in terms of such a world also loses its meaning.

But precisely because of its disconcerting and uncanny nature, anxiety carries great existential potential. By letting the world sink into insignificance, anxiety "reveals the nullity of that with which one can concern oneself' (BT 393/343). That is, anxiety frees Dasein insofar as in anxiety Dasein can project for itself its ownmost possibility. This is because what anxiety makes clear to Dasein is that it is a finite, thrown, burdened being and not a being who is defined solely in terms of its worldly projects (BT 399/344).

It is precisely in the revelatory character of anxiety - and relatedly, in its existential value - that its temporal nature becomes clear. By casting into relief Dasein's thrown, finite nature, anxiety succeeds in bringing Dasein back to itself. Anxiety "brings one back to the pure 'that-it-is' of one's ownmost individualized thrownness" (BT 394/343). But such an act of 
bringing-back is only possible if Dasein's being involves a having been. In other words, anxiety, like fear, is grounded in the having been. But unlike fear, in anxiety Dasein is not turned away from its thrownness. Rather, in anxiety "Dasein is taken all the way back to its naked uncanninness, and becomes fascinated by it" (BT 394/344). Dasein is capable of taking up its thrownness, affirming it, and indeed appropriating it for itself to the extent that it is possible.

Unlike in fear, the mode of having been in the case of anxiety is not that of forgetting. Instead, it is that of repetition or retrieval (Wiederholung) (BT 388/339, 394/343, 437f./385f.). 'Wiederholung' does not signify that Dasein repeats what it or someone else has done before. It isn't a form of mimesis because that would inevitably result in a kind of inauthentic existence: Dasein would not be choosing and delineating its own projects for itself. Rather, repetition is a way of going back to oneself (by retrieving and appropriating one's thrownness) in order to come toward oneself (to determine one's proper ability-to-be) (BT 436-8/385-6). Our possibilities come from our inherited past (having been). As such, in order to become authentic, we have to take over our past.

Repetition, as a mode of having been, modifies both Dasein's future and its present. Repetition is intimately related to anticipatory resoluteness, thus it permits Dasein to authentically comport itself to its future, namely, to anticipate its own death, to individualize itself in light of its mortality, and to direct its life in a way that releases its ownmost abilityto-be (BT 388/339). Together, anticipation and repetition enable an authentic making present, what Heidegger calls the "moment of vision" (Augenblick). "Anxiety brings one into the mood for a possible resolution... [it] holds the moment of vision at the ready " (BT 394/344; cf. 387-388/338). The moment of vision is not a "now," but that which "permits us to encounter for the first time what can be 'in a time' as ready-to-hand or present-at-hand" (BT 388/338; GA 21: 401). In the moment of vision, entities are disclosed to us in a manner that their relationship to our individuality is made clear. In this authentic encounter of innerworldly entities, what really matters to us is shown to us and as a result, Dasein can seize its possibilities and become itself (BT 388/338).

In BT, Heidegger does not go into detail about the temporality of moods other than fear and anxiety; he does, however, concede that his discussion of the temporality of fear and anxiety is not exhaustive of all moods and rightfully anticipates that the reader might want to know more. Thus, in response to the question of the temporal meaning of other 
moods such as the "pallid lack of mood which dominates the 'grey everyday" and "hope, joy, enthusiasm, [and] gaiety" (BT 395/344) he writes: "Not only fear and anxiety, but other moods are founded existentially upon one's having been...even a phenomenon like hope, which seems to be founded wholly upon the future, must be analyzed in much the same way as fear" (ibid.).

Heidegger's analysis of hope (Hoffnung) deserves a brief note, for it is the only example of a positively valenced mood that is discussed, in some detail, in BT. Heidegger's analysis is also idiosyncratic insofar as it is opposes a common understanding of hope that renders it essentially futural. Heidegger makes the case that the very structure of hope as an affective phenomenon is only possible insofar as it is grounded in the originary past. That is to say, the character of hope lies not in the fact that in hoping, Dasein hopes for something in the future (a bonum futurum). Rather, what it means to hope is to hope "for something for oneself [Für-sich-erhoffen]" (BT 395-6/345). In other words, what is characteristic of hope is the fact that it presupposes a relationship to oneself as having been. It presupposes that we can relate to ourselves as thrown into the world, as burdened by our existence, and as capable of taking a hold of our lives. Indeed, only if we already find ourselves as thrown projection, can hope bring "alleviation [erleichtert] from depressing misgivings" (BT 396/345). The temporality of hope then lies not primarily in a future but rather in the past as having been. Hope is thus ontologically possible only for an entity like Dasein whose future is always already determined by one's thrown projection.

\section{Boredom}

In the first part of his 1929/30 lecture course, The Fundamental Concepts of Metaphysics, Heidegger offers detailed analyses of three distinct forms of boredom (Langweile) — literally, a "long while": (1) becoming bored by something (Gelangweiltwerden von etwas), (2) being bored with something (Sichlangweilen bei etwas), and (3) profound boredom (tiefe Langweile). Each form of boredom is distinguished from the others in terms of its relation to how time passes (die Zeit vertreiben) and progressively, each form of boredom becomes (existentially) more fundamental with regard to what it is capable of revealing to us. 
The first form of boredom is the most familiar - what we might identify with our pre-theoretical understanding of boredom - but for Heidegger, it is also the most trivial. It occurs when we are bored by some person, object, or state of affairs. As we all know, being bored is unpleasant. When we experience it, we try to make the time pass by distracting ourselves. Very often though, our attempts to get rid of boredom are in vain. This form of boredom arises, for example, while waiting at the gate for our flight to depart after it has already been delayed for hours with no sign of any imminent departure. In terms of its structure, this form of boredom is characterized by two aspects that are intimately related to one another: it leaves us empty and holds us in limbo (FCM 106-7/160-1). Boredom does the former because it fails to offer us any fulfillment (FCM 103/155): what we find at the airport, for example, does not engage us nor does it promote our interests. Boredom does the latter, for when bored, time drags along. Consequently, that which will bring us fulfillment is postponed (FCM 99-100/150-2, 105/158): in this case, boarding the plane, arriving at our destination, and seeing our loved ones.

The second form of boredom is both more profound (FCM 107/162) and slightly more complicated than the first. In this form of boredom, there is no determinate person or object that is boring (FCM 114/172f.). Rather, what we are bored with is something indeterminate and unfamiliar: something that has the character of 'I know not what' (FCM 114ff/172ff), and that Heidegger ultimately identifies with the passing of time itself (not in the form of time dragging, as in the first form of boredom, but rather in the sense of time standing still). Heidegger's example of the second form of boredom is attending a dinner party, on our own volition, and in an attempt to kill time. At the party, the food, company, and music are all pleasant. Indeed, "[t]here is nothing at all to be found that might have been boring about this evening... Thus we come home quite satisfied" (FCM 109/165). And yet, when we reflect upon the evening and situate it in terms of what was interrupted in order to attend the party and of what is coming in the next days, it dawns on us that we were bored all this time after all.

Importantly, and unlike the first form of boredom, in this case, boredom "arises from out of Dasein itself' (FCM 128/193). It is on account of our comportment towards the evening that boredom arises. Our own decision to partake in such a predictable, and in retrospect dull, event results in an emptiness: the party does not fulfill us. Thus, the second form of boredom, just like the first one, is also characterized by the fact that it leaves us empty. The 
evening carries no existential importance for us and consequently, by attending the party, Heidegger notes, we have left our authentic self behind. Yet, insofar as we have left our authentic self behind, we have also abandoned ourselves entirely to the present of the party and it is in this sense that boredom holds us in limbo (FCM 119-21/179-83). In terms of temporality, our decision to attend the party and to become absorbed by it has modified our having been and future: in a sense, we have forgotten them both. As a result, time appears to stand still: not insofar as it drags on and oppresses us (as it did in the first form of boredom), but rather insofar as our very existential present (the manner in which entities are disclosed to us) is cut off from our past (thrownness) and from our future (projection). This second form of boredom is more profound than the first: not only does it arise out of Dasein itself, but it also reveals an inauthentic modification of our temporal existence.

Profound boredom is the third and deepest form of boredom. It is an extreme, allencompassing, and overwhelming experience in which everything bores us and unlike the first form of boredom, there is no point in fighting it. In profound boredom we stand without any concerns and interests. Profound boredom strips away all identifying characteristics, history, or projects; beings as a whole withdraw, and as with anxiety, they lose all significance. In profound boredom, absolute indifference overtakes us and we become depersonalized. It is neither me, nor you who experiences this form of boredom. Rather, in profound boredom, "it is boring for one" (FCM 134/202). Profound boredom thus renders us "an undifferentiated no one" by disclosing to us a world with no meaning or significance (FCM 135/203).

Profound boredom, like the other two forms of boredom, leaves us empty. But the emptiness in this case is more profound. Nothing matters to us. Nothing attracts us. There is nothing to which we can relate. But somehow, in this total withdrawal (or "telling refusal") of significance, our unexploited possibilities are suddenly revealed (FCM 139-41/209-211). “All telling refusal [Versagen]," Heidegger writes, "is in itself a telling [Sagen], i.e., a making manifest" (FCM 140/211). In other words, in withdrawing and thereby losing their significance - a kind of concealing - entities in the world suddenly and paradoxically reveal themselves to Dasein anew. That is, they disclose possibilities that for the most part remained hidden or forgotten in our everyday life.

The total, utter, and comprehensive withdrawal of meaning and significance that we experience in boredom is, if understood properly, temporal in nature. Total indifference 
means not only that everything around us (or alongside of us) has been drained of meaning (FCM 143/215, 145/217). It also means that nothing carries future prospects for us and that nothing relates and gives meaning to our having been. But such a total withdrawal of beings is possible, Heidegger contends, only if Dasein "can no longer go along with them," if it is "entranced," and if its originary temporality has been modified (FCM 147/221). In profound boredom, all three temporal dimensions of Dasein - past, present, and future - meld together and it is this "unarticulated unity" that entrances Dasein (FCM 148/222). What bores us is not any specific entity or state of affairs; rather, it is time (as originary temporality) itself. Time bores us by entrancing and binding us (FCM 147f./221f., 158/237). But by doing so, time also holds Dasein in limbo: "Entranced by time, Dasein cannot find its way to those beings that announce themselves in the telling refusal of themselves" (FCM 147/221).

What is perhaps most peculiar about profound boredom is that it does not lead to profound despair, as one might expect. This entrancement that both leaves Dasein empty and holds it in limbo also carries the potential for "an exceptional understanding" of the kind of being that Dasein is (FCM 136/205). Entrancement, recall, results not only in the withdrawal of significance but also in the revealing of possibilities proper to Dasein. Indeed, what is revealed to Dasein in this peculiar refusal is its freedom. This revealing acts as a call for action (FCM 148-152/222-28). Dasein is called to resolutely disclose and appropriate itself, that is, to take action in the moment of vision (Augenblick), to choose what is properly its own, and to become the author of its own existential meaning (FCM 149/224).

\section{Moods in Heidegger's Later Thinking}

After 1930, Heidegger's thinking undergoes a shift from having a transcendental focus to an historical one. Likewise, his understanding of mood also undergoes a transformation: moods become less Dasein-centric and more historically oriented. Although evidence of this shift can already be found in "What is Metaphysics?" (1929), The Fundamental Concepts of Metaphysics (1929-30), and On the Essence of Truth (1930), it is not until the mid 1930s that this new conception of moods (as fundamental moods [Grundstimmungen]) develops. ${ }^{11}$ In discussing

\footnotetext{
11 As an anonymous reviewer helpfully points out, Heidegger's discussions of anxiety in "What is Metaphysics?" (1929) and boredom and joy in The Fundamental Concepts of Metaphysics (1929-30) suggest that the notion of Grundstimmung was already in place even as early as in 1929.
} 
the fundamental mood of wonder (Erstaunen), Heidegger states that what makes this mood fundamental is the fact that "it transports the one that it attunes into a domain upon which and within which word, work, and action, as historical, can be founded and history can begin" (GA 45: 170). A fundamental mood does not occur in us, yet it is capable of both transporting us (GA 45: 154; GA 39: 89, 139) and of opening up the world for us in a way that allow entities to be encountered and represented (GA 39: 82). Importantly, a fundamental mood determines our relationship to historical Being. Indeed, it "hands our Dasein over to historical Being in such a way that it must take over, shape, and sustain the latter" (GA 39: 223).

It is Heidegger's position in his later thinking that there are only a small number of historical fundamental moods in each great epoch of Being. Such moods do not merely characterize the epoch: they are not the 'spirit' of the time, nor are they akin to a Weltanschauung. Rather, they are the source of, and atmosphere in which, thinking and action occur. Indeed, they ground both the epoch and history itself. The first beginning of Western thinking (i.e., Presocratic philosophy) arose out of the basic mood of wonder (GA 45: 155ff.; GA 65: 14, 21f.). A new beginning of thinking, however, requires a new basic mood, namely, reserve (Verhaltenheit), which is characterized both by terror and awe. (GA 45: 1f., 196f.; GA 65: 14; cf. GA 9: 306f./233f.)

\section{Conclusion}

In the foregoing discussion we offered a summary of Heidegger's account of originary temporality and explored its relationship to Dasein's distinctive mode of being with the aim of articulating the specific temporality of the ontological structure of Befindlichkeit and of explicating the manner in which originary temporality, in its ecstatic-horizonal, dynamic unity, enables and grounds the different ways of affectively finding oneself. We also discussed fear, anxiety, and boredom, and noted the change that his account of mood undergoes beginning in the 1930s. Yet despite the intricacies, complexity, and novelty of Heidegger's account of affectivity, we would be remiss to conclude without inquiring about the value of his account. What is the importance of Heidegger's discussion of affectivity? What are the merits of such an account? What does it have to offer to our understanding of 
affectivity and human existence? Or to put it plainly, why should we care for what Heidegger says about affectivity?

The value of Heidegger's account, we believe - in particular his account prior to 1930 - lies primarily in its unique capacity to highlight the existential import of affectivity and, relatedly, to cast into sharp relief the fact that affectivity is an irrevocable and essential aspect of our worldly, social, and concernful existence. What it is to be human - to be open to the world, to live in a world full of meaning and value, to care for what you do and what others do to you, and to form and maintain relationships with others - is predicated on our capacity to affectively find ourselves in the world. Affectivity constitutes an integral part of human existence, but, importantly, it is not separate from whatever else makes us humans (for Heidegger: understanding, falling, and discourse). To be affected is to already find oneself in the midst of a specific and holistically meaningful situation, burdened by one's existence, and as always striving to realize one's possibilities. Affectivity shows us that we are here; it tells us how we are faring; and it 'pushes' us to become who we want to be. A philosophical study of affectivity that follows the basic contours of Heidegger's account carries the prospect of coming to terms with our human predicament.

\section{REFERENCES}

Blattner, William. "Temporality." A Companion to Heidegger. Edited by Hubert. L. Dreyfus and Mark Wrathall. Oxford: Blackwell Publishers, 2005: 311- 324.

------. "Authenticity and Resoluteness." The Cambridge Companion to Heidegger's Being and Time. Edited by Mark Wrathall. New York: Cambridge University Press, 2013: 320-337.

Carman, Taylor. "Authenticity." A Companion to Heidegger. Edited by Hubert. L. Dreyfus and Mark Wrathall. Oxford: Blackwell Publishers, 2005: 285-296.

Dahlstrom, Daniel. Heidegger's Concept of Truth. Cambridge: Cambridge University Press, 2001.

------. "Authenticity and the Absence of Death." Heidegger, Authenticity and the Self: Themes from Division Two of Being and Time. Edited by Denis McManus. New York: Routledge, 2015: 146-162.

Elpidorou, Andreas and Lauren Freeman. "Affectivity in Heidegger I: Moods and Emotions in Being and Time." Philosophy Compass 2015: 1-11.

Guignon, Charles. "Philosophy and authenticity: Heidegger's search for a ground for philosophizing." Heidegger, Authenticity, and Modernity: Essays in Honor of Hubert L. Dreyfus, 
Volume 1. Edited by Mark Wrathall and Jeff Malpas. Cambridge, MA: MIT Press, 2000: 79102.

---------."Becoming a Self: The Role of Authenticity in Being and Time." The Existentialists: Critical Essays on Kierkegaard, Nietzsche, Heidegger, and Sartre. Edited by Charles Guignon. Lanham: Rowman \& Littlefield, 2004: 119-32.

Heidegger, Martin. Sein und Zeit. GA 2. Tübingen: Max Niemeyer Verlag, 1927. (Being and Time. Trans. Macquarrie and Robinson. New York: Harper \& Row Publishers, 1962.)

-------. Wegmarken (1919-1961). GA 9. Edited by F.-W. von Herrmann. Frankfurt am Main: Vittorio Klostermann, 1976. (Pathmarks. Edited William McNeil, multiple translators. New York: Cambridge University Press, 1998.)

--------. Prolegomena zur Geschichte des Zeitbegriffs. GA 20. Frankfurt am Main: Vittorio Klostermann, 1979. (History of the Concept of Time: Prolegomena. Trans. Theodore Kisiel. Bloomington: Indiana University Press, 1992.)

--------. Logik: Die frage nach der W abrheit. 1925. GA 21. Frankfurt am Main: Vittorio Klostermann, 1995 (Logic: The Question of Truth. Translated by Thomas Sheehan.

Bloomington: Indiana University Press, 2010.

-. Metaphysische Anfangsgründe der Logik im Ausgang von Leibniz. 1928/2007. GA 26.

Frankfurt am Main: Vittorio Klostermann, (The Metaphysical Foundations of Logic. Translated by Michael Heim. Bloomington: Indiana University Press, 1984.)

Die Grundbegriffe der Metaphysik. Welt, Endlichkeit, Einsamkeit. GA 29/30. Frankfurt am Main: Vittorio Klostermann, 1929-30/1983. (Basic Concepts of Metaphysics: WorldFinitude-Solitude. Trans. by W. McNeil/N. Walker. Bloomington, Indiana 1995.)

---------. Hölderlins Hymnen “Germanien” und "DerRhein”. 1934. GA 39. Frankfurt am Main: Vittorio Klostermann, 1999.

--------. Grundfragen der Philosophie. Ausgewählte "Probleme" der "Logik." GA 45. Frankfurt am Main: Vittorio Klostermann, 1984. (Basic Questions of Philosophy Selected "Problems" of "Logic." Translated by Richard Rojcewicz and Andre Schuwer. Bloomington: Indiana University Press, 1994.)

--------. Beiträge zur Philosophie (vom Ereignis). Frankfurt am Main: Klostermann, 1989. (Contributions to Philosophy (From Enowning). Translated by Parvis Emad and Kenneth Maly/ Bloomington: Indiana University Press, 1999).

Hoffman, Piotr. "Dasein and "its" Time." A Companion to Heidegger. Edited by Hubert. L. Dreyfus and Mark Wrathall. Oxford: Blackwell Publishers, 2005: 325-334.

Käufer, Stephan. "Temporality as the Ontological Sense of Care." The Cambridge Companion to Heidegger's Being and Time. Edited by Mark Wrathall. New York: Cambridge University Press, 2013: 338-359. 
Mulhall, Stephen. Routledge Philosophy Guidebook to Heidegger and Being and Time. 2nd ed. New York: Routledge, 2005.

Polt, Richard. Heidegger: An Introduction. Ithaca: Cornell University Press, 1999.

Slaby, Jan. "Affectivity and Temporality in Heidegger." Feeling and Value, Willing and Action. Phaenomenologica 216. Edited by Marta Ubiali \& Maren Wehrle. Dordrecht: Springer, 2015: 183-206.

Vallega-Neu, Daniela. Heidegger's Contributions to Philosophy: An Introduction. Bloomington: Indiana University Press, 2003. 